\title{
A new minute species of Pristimantis (Amphibia: Anura: Craugastoridae) with a large head from the Yanachaga-Chemillén National Park in central Peru, with comments on the phylogenetic diversity of Pristimantis occurring in the Cordillera Yanachaga
}

\author{
Edgar LEHR ${ }^{1, *}$, Jiří MORAVEC ${ }^{2}$, Juan Carlos CUSI ${ }^{3}$ \& Václav GVOŽDÍK ${ }^{4,5}$ \\ ${ }^{1}$ Department of Biology, Illinois Wesleyan University, P.O. Box 2900, Bloomington, IL, 61701, USA. \\ ${ }^{2,5}$ Department of Zoology, National Museum, Cirkusová 1740, 19300 Prague 9, Czech Republic. \\ ${ }^{3}$ Departamento de Herpetología, Museo de Historia Natural Universidad Nacional \\ Mayor de San Marcos, Av. Arenales 1256, Jesús María, Lima, Peru. \\ ${ }^{4}$ Institute of Vertebrate Biology, Czech Academy of Sciences, Brno, Czech Republic. \\ *Corresponding author: elehr@iwu.edu \\ 2Email: jiri.moravec@nm.cz \\ ${ }^{3}$ Email: jcarloscusim@gmail.com \\ ${ }^{4}$ Email: vaclav.gvozdik@gmail.com \\ ${ }^{1}$ urn:1sid:zoobank.org:author:1BA88866-282D-4349-8CEA-7B6731781915 \\ ${ }^{2}$ urn:lsid:zoobank.org:author:860D3E6B-8AC6-48A5-A94E-47F2F0CFFB72 \\ ${ }^{3}$ urn:lsid:zoobank.org:author:6BA95434-F8A0-410D-9F2A-DC35BEF01F2B \\ ${ }^{4}$ urn:1sid:zoobank.org:author:BF30E84D-46C5-45EE-9140-E7E2154D9A66
}

\begin{abstract}
We describe a new minute species of the genus Pristimantis, P. boucephalus sp. nov., from the Yanachaga-Chemillén National Park, Región Pasco, Peru. The description is based on a freshly collected male specimen found at $2950 \mathrm{~m}$ a.s.1. in a cloud forest and four previously unidentified museum specimens consisting of two adult males, one subadult female and a juvenile from the Yanachaga-Chemillén National Park. The new species is mainly characterized by a snout-vent length of $13.4-14.5 \mathrm{~mm}$ in adult males $(\mathrm{n}=3)$, and $12.5 \mathrm{~mm}$ in the only known subadult female, and is compared morphologically and genetically with other taxonomically and biogeographically relevant species of Pristimantis. The new species is characterized by its small size, disproportionally large head with short snout, absence of a tympanic annulus and membrane, and reddish-copper iris. Phylogenetically it belongs to a speciose clade, an as yet unnamed species group, comprising both montane (Andes, Guiana Shield) and lowland (Amazon) taxa from the northern part of South America. The new species is genetically close to the sympatric P. cruciocularis. Species of Pristimantis occurring in the Cordillera Yanachaga region in the Andes of central Peru are members of six divergent phylogenetic lineages.
\end{abstract}

Keywords. Andes, DNA barcoding, frogs, molecular phylogeny, new species.

Lehr E., Moravec J., Cusi J.C. \& Gvoždík V. 2017. A new minute species of Pristimantis (Amphibia: Anura: Craugastoridae) with a large head from the Yanachaga-Chemillén National Park in central Peru, with comments on the phylogenetic diversity of Pristimantis occurring in the Cordillera Yanachaga. European Journal of Taxonomy 325: 1-22. https://doi.org/10.5852/ejt.2017.325 


\section{Introduction}

In the area of the Selva Central of Peru (Regions of Pasco and Junín, central Peru), there are twelve natural areas with different levels of legal protection such as national parks, national sanctuaries, national reserves and others of lower protection categories (SERNANP 2010). In 2012 we started surveying the herpetofauna of the Yanachaga-Chemillén National Park (hereafter YCNP; Región Pasco, Fig. 1), with the aim to obtain a better knowledge of the anuran species richness of the YCNP and to provide data needed for an effective protection of the park. The expeditions in the YCNP led to the discovery of several new species of amphibians (e.g., Phrynopus badius Lehr, Moravec \& Cusi, 2012, Phrynopus curator Lehr, Moravec \& Cusi, 2012 and Rhinella yunga Moravec, Lehr, Cusi, Córdova \& Gvoždík, 2014). Among the new findings was an undescribed species of Pristimantis Jiménez de la Espada, 1870 readily distinguishable from its local congeners by its small size with a disproportionally large head, short snout, and reddish-copper iris. However, because only a single male specimen was available at that time, we refrained from formally describing it. Revision of specimens from the YCNP housed in the herpetological collection of the Museo de Historia Natural Universidad Nacional Mayor de San Marcos (Lima, Peru) in 2015 led to the discovery of four additional specimens (labeled Pristimantis sp.) of the same taxon. Close examination of the five specimens revealed that they bear several morphological characteristics not shared by any other described species of Pristimantis in Peru. Therefore, we describe the new species and compare it morphologically and genetically with other taxonomically and biogeographically relevant species of Pristimantis from Bolivia, Ecuador, Peru, the Guyanas, and Venezuela. A phylogenetic analysis provided additional insights into the phylogenetic diversity of Pristimantis from the area of the Cordillera Yanachaga.

\section{Material and methods}

\section{Morphological characters}

The format for the description follows Lynch \& Duellman (1997), and diagnostic characters are those of Duellman \& Lehr (2009). Taxonomic classification follows Hedges et al. (2008) and Heinicke et al. (2009), except that we followed Pyron \& Wiens (2011) for family placement and Padial et al. (2014) for names of Pristimantis species groups. We consider minute species of amphibians as having an adult snout-vent length (SVL) below $20 \mathrm{~mm}$, as suggested by Clarke (1996). The holotype was fixed in 96\% ethanol and stored in 70\% ethanol. Liver tissue of the holotype was taken for genetic analyses. Sex and maturity of specimens were identified by observing secondary sexual characters (vocal slits), and gonads through dissections. Specimens with a SVL $\leq 10 \mathrm{~mm}$ were considered juveniles when gonads were too small to distinguish between sexes. We used maximum known SVL for males within a species to recognize smallest body size as recommended by Lehr \& Coloma (2008). We measured the following variables to the nearest $0.1 \mathrm{~mm}$ with digital calipers under a stereo microscope: snout-vent length (SVL, straight length distance from tip of snout to vent), tibia length (TL, distance from the knee to the distal end of the tibia), foot length (FL, distance from proximal margin of inner metatarsal tubercle to tip of Toe IV), head length (HL, from angle of jaw to tip of snout), head width (HW, at level of angle of jaw), horizontal eye diameter (ED), interorbital distance (IOD), upper eyelid width (EW), internarial distance (IND), eye-nostril distance (E-N, straight line distance between anterior corner of orbit and posterior margin of external nares). Fingers and toes are numbered preaxially to postaxially as I-IV and I-V, respectively. We compared the lengths of Toes III and V by adpressing both toes against Toe IV; lengths of Fingers I and II were compared by adpressing the fingers against each other. To avoid reflection, the preserved holotype was photographed immersed in ethanol. All drawings were made by JM using a stereo microscope and a camera lucida. Photographs taken by JM and EL were used for descriptions of coloration in life. Comparisons of congeners focused on species with similar SVL from Ecuador and Peru and genetically close species as recovered in our trees. Information on species for comparative diagnoses was obtained from Duellman \& Lehr (2009) and from original species descriptions. For specimens examined see Appendix. 




Fig. 1. Map of Peru with the Yanachaga-Chemillén National Park indicated in red. 
Codes of collections are:

$\mathrm{KU}=$ University of Kansas, Museum of Natural History, Lawrence, KS, USA

MUSM $=$ Museo de Historia Natural Universidad Nacional Mayor de San Marcos, Lima, Peru

NMP6V = National Museum Prague, Prague, Czech Republic

SMNS = Staatliches Museum für Naturkunde Stuttgart, Stuttgart, Germany

USNM = National Museum of Natural History, Smithsonian Institution, Washington DC, USA

Threat status was evaluated using the IUCN criteria (2016).

\section{Molecular analysis}

\section{Taxon sampling}

We included samples of various Pristimantis species collected by us in the YCNP during a survey in 2012, and from the nearby Bosque de Shollet Protected Area (BS) and Pui Pui Protected Forest (PPPF) collected between 2012 and 2014. The aim was to detect phylogenetic diversity of Pristimantis species distributed in these and nearby montane regions of the Cordillera Yanachaga. Most of the specimens were identified to species level, with the exception of the single 'bigheaded' male (mentioned above) and a few specimens from the Pui Pui forest, which are tentatively named Pristimantis sp. Pui Pui. A list of the newly genetically investigated material and its GenBank accession numbers is in Table 1. For the final dataset, we retrieved additional sequences conspecific with our samples from GenBank to show phylogenetic positions of our new material in relation to DNA sequences published earlier (most importantly in the review by Hedges et al. 2008). We also retrieved and included species known to occur in the Cordillera Yanachaga region (Duellman \& Hedges 2005, 2007) but not recorded by us (P. albertus Duellman \& Hedges, 2007, P. minutulus Duellman \& Hedges, 2007, P. stictogaster (Duellman \& Hedges, 2005), P. sagittulus (Lehr, Aguilar \& Duellman, 2004)). In addition, we specifically focused on the 'bigheaded' specimen and applied a BLAST search (Altschul et al. 1990) using the BLASTN v. 2.3.1 program (Zhang et al. 2000; Morgulis et al. 2008) for the most similar DNA sequences available in GenBank based on the 16S rRNA gene fragment (see below). We selected and included into our dataset sequences of species or main evolutionary lineages of species complexes (e.g., the $P$. platydactylus complex) with nucleotide sequence identity in relation to our 'bigheaded' specimen $\geq$ $90 \%$, and which formed a clade in the BLAST minimum-evolution tree. We also included species from the sister clade, which also contained one species known from the YCNP, P. minutulus. As outgroups, we used the craugastorid genera Oreobates Jiménez de la Espada, 1872 (O. cruralis (Boulenger, 1902)) and Phrynopus Peters, 1873 (P. bracki Hedges, 1990), retrieved from GenBank. The final dataset was composed of 87 samples of 37 nominal taxa, including the new species and outgroups. All sequences acquired from GenBank can be identified by the GenBank accession numbers as given in Fig. 2.

\section{DNA extraction, PCR, sequencing and sequence alignment}

Genomic DNA was extracted from tissues stored in $96 \%$ ethanol. A fragment of the mitochondrial gene for 16S rRNA (16S), which is commonly used in amphibian DNA barcoding (Vences et al. 2012), was targeted using the primers $16 \mathrm{SL} 1$ and $16 \mathrm{SH} 1$ adapted or directly taken from Palumbi et al. (1991). For primer sequences and PCR conditions see Moravec et al. (2009). Sequencing was performed by using the PCR primers. Additionally, a newly designed internal primer (prist16SinR1: 5'-ATGTTTTAAGCTCCA-3') had to be used for the 'bigheaded' Pristimantis to overcome a problem with a G-C homopolymer region in the middle of the fragment. New sequences have been deposited in GenBank (KY006082-006112). The multiple sequence alignment was performed using MAFFT v. 7.1 (Katoh \& Standley 2013), producing a 561 bp long alignment. Ambiguously aligned positions were eliminated by Gblocks v. 0.91 b under options for a less stringent selection (Castresana 2000), producing a final alignment of $510 \mathrm{bp}$. 
Table 1. Names of taxa, field numbers, museum numbers, field data, and GenBank accession numbers of newly genetically investigated material. The new species is indicated in bold. For abbreviations see text.

\begin{tabular}{|c|c|c|c|c|c|c|}
\hline Taxon & $\begin{array}{c}\text { Field } \\
\text { numbers }\end{array}$ & $\begin{array}{c}\text { Museum } \\
\text { number }\end{array}$ & Locality & Coordinates & Elevation & $\begin{array}{c}\text { GenBank } \\
\text { Accession } \\
\text { numbers }\end{array}$ \\
\hline P. aniptopalmatus & IWU28 & MUSM 31111 & YCNP & $10^{\circ} 23.718^{\prime} \mathrm{S}, 75^{\circ} 28.919^{\prime} \mathrm{W}$ & $2290 \mathrm{~m}$ & KY006082 \\
\hline P. aniptopalmatus & IWU58 & MUSM 31128 & YCNP & $10^{\circ} 40.531^{\prime} \mathrm{S}, 75^{\circ} 19.2897^{\prime} \mathrm{W}$ & $2430 \mathrm{~m}$ & KY006083 \\
\hline P. aniptopalmatus & IWU64 & MUSM 31130 & YCNP & $10^{\circ} 40.531^{\prime} \mathrm{S}, 75^{\circ} 19.2897^{\prime} \mathrm{W}$ & $2430 \mathrm{~m}$ & KY006084 \\
\hline P. aniptopalmatus & IWU97 & MUSM 31151 & YCNP & $10^{\circ} 39^{\prime} 05.7^{\prime \prime} \mathrm{S}, 75^{\circ} 17^{\prime} 39.3^{\prime \prime} \mathrm{W}$ & $2836 \mathrm{~m}$ & KY006085 \\
\hline P. aniptopalmatus & IWU272 & NMP6V 75051 & PPPF & $11^{\circ} 07^{\prime} 40.6^{\prime \prime} \mathrm{S}, 75^{\circ} 11^{\prime} 15.7^{\prime \prime} \mathrm{W}$ & $2230 \mathrm{~m}$ & KY006086 \\
\hline P. aniptopalmatus & IWU265 & NMP6V 75053 & PPPF & $11^{\circ} 07^{\prime} 40.6^{\prime \prime} \mathrm{S}, 75^{\circ} 11^{\prime} 15.7^{\prime \prime} \mathrm{W}$ & $2230 \mathrm{~m}$ & KY006087 \\
\hline P. cf. aniptopalmatus & IWU18 & - & YCNP & $10^{\circ} 22.772^{\prime} \mathrm{S}, 75^{\circ} 23.717^{\prime} \mathrm{W}$ & $2950 \mathrm{~m}$ & KY006088 \\
\hline P. bipunctatus & IWU46 & MUSM 31120 & YCNP & $10^{\circ} 23.718^{\prime} \mathrm{S}, 75^{\circ} 28.919^{\prime} \mathrm{W}$ & $2290 \mathrm{~m}$ & KY006089 \\
\hline P. bipunctatus & IWU346 & NMP6V 75062 & PPPF & $11^{\circ} 12^{\prime} 38.5^{\prime \prime} \mathrm{S}, 74^{\circ} 57^{\prime} 28.9^{\prime \prime} \mathrm{W}$ & $1700 \mathrm{~m}$ & KY006090 \\
\hline P. boucephalus sp. nov. & IWU14 & MUSM 31102 & YCNP & $10^{\circ} 22.772^{\prime} \mathrm{S}, 7^{\circ} 23.717^{\prime} \mathrm{W}$ & $2950 \mathrm{~m}$ & KY006091 \\
\hline P. cruciocularis & IWU43 & - & YCNP & $10^{\circ} 23.718^{\prime} \mathrm{S}, 75^{\circ} 28.919^{\prime} \mathrm{W}$ & $2290 \mathrm{~m}$ & KY006092 \\
\hline P. cruciocularis & IWU79 & - & YCNP & $10^{\circ} 26.688^{\prime} \mathrm{S}, 75^{\circ} 26.773^{\prime} \mathrm{W}$ & $2100 \mathrm{~m}$ & KY006093 \\
\hline P. cruciocularis & IWU226 & NMP6V 75070 & PPPF & $11^{\circ} 06^{\prime} 17.0^{\prime \prime} \mathrm{S}, 75^{\circ} 12^{\prime} 26.2^{\prime \prime} \mathrm{W}$ & $1730 \mathrm{~m}$ & KY006094 \\
\hline P. cruciocularis & IWU240 & NMP6V 75071 & PPPF & $11^{\circ} 07^{\prime} 37.2^{\prime \prime} \mathrm{S}, 75^{\circ} 10^{\prime} 37.0^{\prime \prime} \mathrm{W}$ & $1970 \mathrm{~m}$ & KY006095 \\
\hline P. cf. mendax & IWU07 & - & YCNP & $10^{\circ} 22.772^{\prime} \mathrm{S}, 75^{\circ} 23.717^{\prime} \mathrm{W}$ & $2950 \mathrm{~m}$ & KY006096 \\
\hline P. cf. mendax & IWU12 & - & YCNP & $10^{\circ} 22.772^{\prime} \mathrm{S}, 75^{\circ} 23.717^{\prime} \mathrm{W}$ & $2950 \mathrm{~m}$ & KY006097 \\
\hline P. cf. mendax & IWU67 & MUSM 31133 & YCNP & $10^{\circ} 40.531^{\prime} \mathrm{S}, 75^{\circ} 19.2897^{\prime} \mathrm{W}$ & $2430 \mathrm{~m}$ & KY006098 \\
\hline P. cf. mendax & IWU68 & - & YCNP & $10^{\circ} 40.531^{\prime} \mathrm{S}, 75^{\circ} 19.2897^{\prime} \mathrm{W}$ & $2430 \mathrm{~m}$ & KY006099 \\
\hline P. cf. mendax & IWU99 & - & YCNP & $10^{\circ} 39^{\prime} 05.7^{\prime \prime} \mathrm{S}, 75^{\circ} 17^{\prime} 39.3^{\prime \prime} \mathrm{W}$ & $2836 \mathrm{~m}$ & KY006100 \\
\hline P. rhabdocnemus & IWU26 & - & YCNP & $10^{\circ} 23.718^{\prime} \mathrm{S}, 75^{\circ} 28.919^{\prime} \mathrm{W}$ & $2290 \mathrm{~m}$ & KY006101 \\
\hline P. rhabdocnemus & IWU31 & - & YCNP & $10^{\circ} 23.718^{\prime} \mathrm{S}, 75^{\circ} 28.919^{\prime} \mathrm{W}$ & $2290 \mathrm{~m}$ & KY006102 \\
\hline P. rhabdocnemus & IWU37 & MUSM 31116 & YCNP & $10^{\circ} 23.718^{\prime} \mathrm{S}, 75^{\circ} 28.919^{\prime} \mathrm{W}$ & $2290 \mathrm{~m}$ & KY006103 \\
\hline P. rhabdocnemus & IWU41 & MUSM 31119 & YCNP & $10^{\circ} 23.718^{\prime} \mathrm{S}, 75^{\circ} 28.919^{\prime} \mathrm{W}$ & $2290 \mathrm{~m}$ & KY006104 \\
\hline P. rhabdocnemus & IWU42 & - & YCNP & $10^{\circ} 23.718^{\prime} \mathrm{S}, 75^{\circ} 28.919^{\prime} \mathrm{W}$ & $2290 \mathrm{~m}$ & KY006105 \\
\hline P. rhabdocnemus & IWU44 & - & YCNP & $10^{\circ} 23.718^{\prime} \mathrm{S}, 75^{\circ} 28.919^{\prime} \mathrm{W}$ & $2290 \mathrm{~m}$ & KY006106 \\
\hline P. rhabdocnemus & IWU48 & MUSM 31122 & YCNP & $10^{\circ} 23.718^{\prime} \mathrm{S}, 75^{\circ} 28.919^{\prime} \mathrm{W}$ & $2290 \mathrm{~m}$ & KY006107 \\
\hline P. rhabdocnemus & IWU71 & MUSM 31134 & BS & $10^{\circ} 40.531^{\prime} \mathrm{S}, 75^{\circ} 19.2897^{\prime} \mathrm{W}$ & $2430 \mathrm{~m}$ & KY006108 \\
\hline P. rhabdocnemus & IWU73 & - & BS & $10^{\circ} 40.531^{\prime} \mathrm{S}, 75^{\circ} 19.2897^{\prime} \mathrm{W}$ & $2430 \mathrm{~m}$ & KY006109 \\
\hline$P$. sp. Pui Pui & IWU388 & NMP6V 75063 & PPPF & $11^{\circ} 12^{\prime} 38.5^{\prime \prime} \mathrm{S}, 74^{\circ} 57^{\prime} 28.9^{\prime \prime} \mathrm{W}$ & $1700 \mathrm{~m}$ & KY006110 \\
\hline P. sp. Pui Pui & IWU377 & NMP6V 75064 & PPPF & $11^{\circ} 12^{\prime} 38.5^{\prime \prime} \mathrm{S}, 74^{\circ} 57^{\prime} 28.9^{\prime \prime} \mathrm{W}$ & $1700 \mathrm{~m}$ & KY006111 \\
\hline$P$. sp. Pui Pui & IWU344 & NMP6V 75065 & PPPF & $11^{\circ} 12^{\prime} 38.5^{\prime \prime} \mathrm{S}, 74^{\circ} 57^{\prime} 28.9^{\prime \prime} \mathrm{W}$ & $1700 \mathrm{~m}$ & KY006112 \\
\hline
\end{tabular}

\section{Phylogenetic analysis}

The Bayesian inference (BI) was applied to construct a phylogenetic tree. First, the software jModelTest v. 2.1.7 (Darriba et al. 2012) using the PhyML algorithm (Guindon \& Gascuel 2003) was used to find the best-fitting model of nucleotide evolution, which was the GTR $+\mathrm{I}+\mathrm{G}$ model based on both the Akaike and Bayesian information criteria. The BI analysis was run in MrBayes v. 3.2.5 (Ronquist et al. 2012), with two runs and four chains in each run for $6 \times 10^{6}$ generations, sampling every $100^{\text {th }}$ generation. Appropriate sampling was controlled by examining the stationarity of log-likelihood scores against the generation time using Tracer v. 1.6 (Rambaut et al. 2013; all parameters had effective sample size $>1000$ ), and convergence between the two simultaneous runs was confirmed by the convergence diagnostics of the average standard deviation of split frequencies and the potential scale reduction factor values. From the sampled trees, $25 \%$ were discarded as a burn-in and a $50 \%$ majority-rule consensus tree was produced from the remaining post burn-in trees. The posterior probabilities (pp) were calculated as the frequency of samples recovering any particular clade. Clades supported with pp values $\geq 0.95$ were considered highly supported (Huelsenbeck \& Rannala 2004). Genetic uncorrected $p$-distances were calculated in PAUP* (Swofford 2003). 


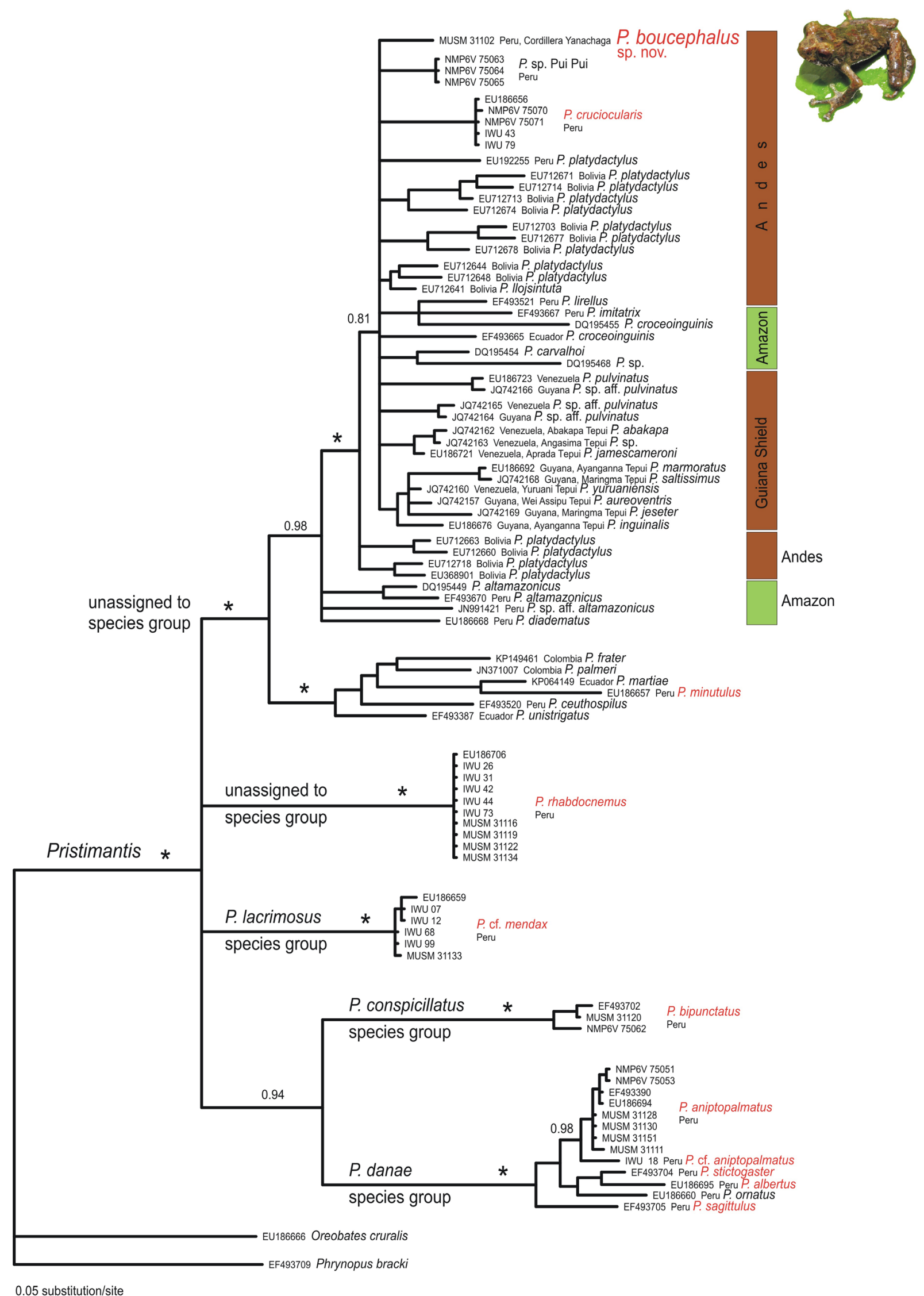




\section{Results}

\section{Molecular analysis}

Our morphology-based species identifications of taxa recorded in the Cordillera Yanachaga were supported by $16 S$ DNA barcodes as they were identical or closely related to haplotypes available in GenBank (Pristimantis aniptopalmatus (Duellman \& Hedges, 2005), P. bipunctatus (Duellman \& Hedges, 2005), P. cruciocularis (Lehr, Lundberg, Aguilar \& von May, 2006), P. cf. mendax (Duellman, 1978), P. rhabdocnemus (Duellman \& Hedges, 2005)). The inferred phylogenetic tree (Fig. 2) showed that species of Pristimantis occurring in the Cordillera Yanachaga and nearby regions belonged to at least six deeply divergent lineages (marked as species groups in Fig. 2). Five species (including samples retrieved from GenBank) clustered together forming a well-supported lineage: P. albertus, P. aniptopalmatus, P. ornatus (Lehr, Lundberg, Aguilar \& von May, 2006) (from a site near the Cordillera Yanachaga), P. sagittulus, and P. stictogaster. We also uncovered one distinct lineage within 'P. aniptopalmatus' (3.8\% average genetic uncorrected $p$-distance to other 'conspecifics'), which we tentatively name $P$. cf. aniptopalmatus. Pristimantis bipunctatus, $P$. cf. mendax, $P$. minutulus (taken from GenBank), and $P$. rhabdocnemus are members of four other divergent lineages. The 'bigheaded' Pristimantis from the YCNP is, together with $P$. sp. Pui Pui from the geographically close PPPF and P. cruciocularis from both the YCNP and PPPF, a member of another lineage. This lineage represents a speciose clade, which comprises montane species from the Andes and the Guiana Shield and also lowland species from the intervening Amazon lowlands. The topology within this clade is not resolved, but the clade is highly supported ( $\mathrm{pp}=0.98)$. Among the sympatric species, the genetically closest of the 'bigheaded' Pristimantis is $P$. cruciocularis, with a genetic uncorrected $p$-distance of $5.8 \%$. The genetic uncorrected $p$-distances among the main lineages range between 13 and 17\%.

\section{Description of new species}

Order Anura Fischer von Waldheim, 1813

Superfamily Brachycephaloidea Günther, 1858

Family Craugastoridae Hedges, Duellman \& Heinicke, 2008

Subfamily Ceuthomantinae Heinicke, Duellman, Trueb, Means, MacCulloch \& Hedges, 2009

Genus Pristimantis Jiménez de la Espada, 1870

Pristimantis boucephalus sp. nov.

urn:1sid:zoobank.org:act:BCF78234-F3F2-4A81-AE80-1B4BE26B1E1F

Figs 3-7, Tables 1-4

Pristimantis sp. 4 - Angulo et al. 2016: 4, figs 76-77.

Suggested English name: Bigheaded Rubber Frog.

Suggested Spanish name: Rana cutín cabezona.

Fig. 2 (opposite page). The Bayesian phylogenetic tree of selected South American Pristimantis; for taxon sampling design see Material and methods. Nodes were collapsed if they appeared in less than $50 \%$ of the post burn-in tree samples. Support values of posterior probabilities (pp) given only for discussed lineages (stars indicate full support, $\mathrm{pp}=1.00$ ). Taxa in red occur in the Cordillera Yanachaga region and represent six divergent lineages/species groups (uncorrected $p$-distance 13-17\%). The new species, $P$. boucephalus sp. nov., is a member of a speciose clade, an as yet unnamed species group, comprising both montane taxa from the Andes and Guiana Shield, and lowland taxa from the intervening Amazon Basin. Species-group names follow Padial et al. (2014). DNA sequences of taxa retrieved from GenBank are labelled by standard GenBank accession numbers, all other codes stand for our new material. 


\section{Etymology}

The species epithet boucephalus is derived from the Greek prefix "bou-" meaning large, huge, or great, and the Greek noun "cephalo" meaning head. The name refers to the disproportionally large head of the new species.

\section{Material examined}

\section{Holotype}

PERU: Ô, adult (Figs 3-5), Yanachaga-Chemillén National Park (Sector San Daniel), Distrito de Huancabamba, Provincia de Oxapampa, Región Pasco, Quebrada Yanachaga, $10^{\circ} 22^{\prime} 46.3$ S, 75²7'43.0 W, 2950 m a.s.1., Edgar Lehr, Juan C. Cusi and Jiři Moravec leg., 19 Jan. 2012 at 20h30 (MUSM 31102, GenBank 16S rRNA barcode: KY006091).

\section{Paratypes $(n=4)$}

PERU: 2 $\widehat{\partial}$ (MUSM 24477-78), 1 subadult 9 (MUSM 24479) and 1 juvenile (MUSM 24474), all from the Yanachaga-Chemillén National Park (based on field numbers, detailed collecting data missing), collected during the 1990s, Javier Icochea leg., see Fig. 6.

\section{Generic placement}

We assign this species to Pristimantis based on its general morphological similarity to other members of the genus and our molecular data (Fig. 2).

\section{Definition}

A new species of Pristimantis, not assigned to any species group, having the following combination of characters: (1) Skin on dorsum smooth with few low scattered tubercles, skin on venter areolate with low scattered tubercles; discoidal and thoracic folds absent; dorsolateral folds absent; (2) tympanic membrane and tympanic annulus absent; (3) snout short, rounded in dorsal and lateral views; (4) upper eyelid with one enlarged conical tubercle at its center and one enlarged conical tubercle at its posterior end; EW slightly shorter than IOD; cranial crests absent; (5) dentigerous processes of vomers absent; (6) males with vocal slits, nuptial pads absent; (7) Finger I shorter than Finger II; discs of digits expanded, rounded; (8) fingers with lateral fringes; (9) small conical ulnar and tarsal tubercles present; (10) heel with a conical tubercle; inner tarsal fold absent; (11) inner metatarsal tubercle ovoid, 2.5 times as large as outer; outer metatarsal tubercle small, rounded; numerous low, supernumerary plantar tubercles; (12) toes with lateral fringes; basal toe webbing present; Toe V longer than Toe III; toe discs slightly smaller than those on fingers; (13) in life, dorsal ground coloration greenish gray with reddishbrown blotches and scattered brown flecks surrounded by black; canthal and supratympanic stripes absent; groin and anterior surfaces of thighs greenish yellow with black blotches; venter gray with pale reddish and greenish brown mottling and scattered dark gray flecks; iris reddish copper with fine black vermiculation and black narrow vertical streak from pupil across lower half of iris; (14) SVL in adult males 13.4-14.5 mm $(\mathrm{n}=3)$, in adult females unknown ( $12.5 \mathrm{~mm}$ in single subadult female).

\section{Differential diagnosis}

Pristimantis boucephalus sp. nov. is readily distinguished from its congeners in Ecuador and Peru by its minute SVL, short snout, absence of a tympanum, large head, groin and anterior surfaces of thighs greenish yellow with black blotches, and reddish-copper iris. It is currently one of the smallest of the 130 species of Pristimantis from Peru (AmphibiaWeb 2017) and the 199 species of Pristimantis from Ecuador (Ron et al. 2017, see Table 2).

Pristimantis boucephalus sp. nov. can be distinguished from other minute Andean species of Pristimantis from Ecuador (P. andinognomus, P. minimus, P. trachyblepharis) and Peru (P. caeruleonotus, 
P. coronatus, $P$. minutulus, $P$. trachyblepharis) as follows (characters of $P$. boucephalus in parenthesis, if not otherwise stated):

Pristimantis minutulus Duellman \& Hedges, 2007 from elevations of 250-1200 m a.s.1. in central Peru has larger males (SVL 13.1-17.6 mm [n =7] vs 13.4-14.5 mm [n =3] in P. boucephalus sp. nov.; Duellman \& Hedges 2007). Pristimantis minutulus and P. boucephalus sp. nov. lack dorsolateral folds, discoidal folds, a tympanum, and dentigerous processes of vomers and both have a smooth dorsum

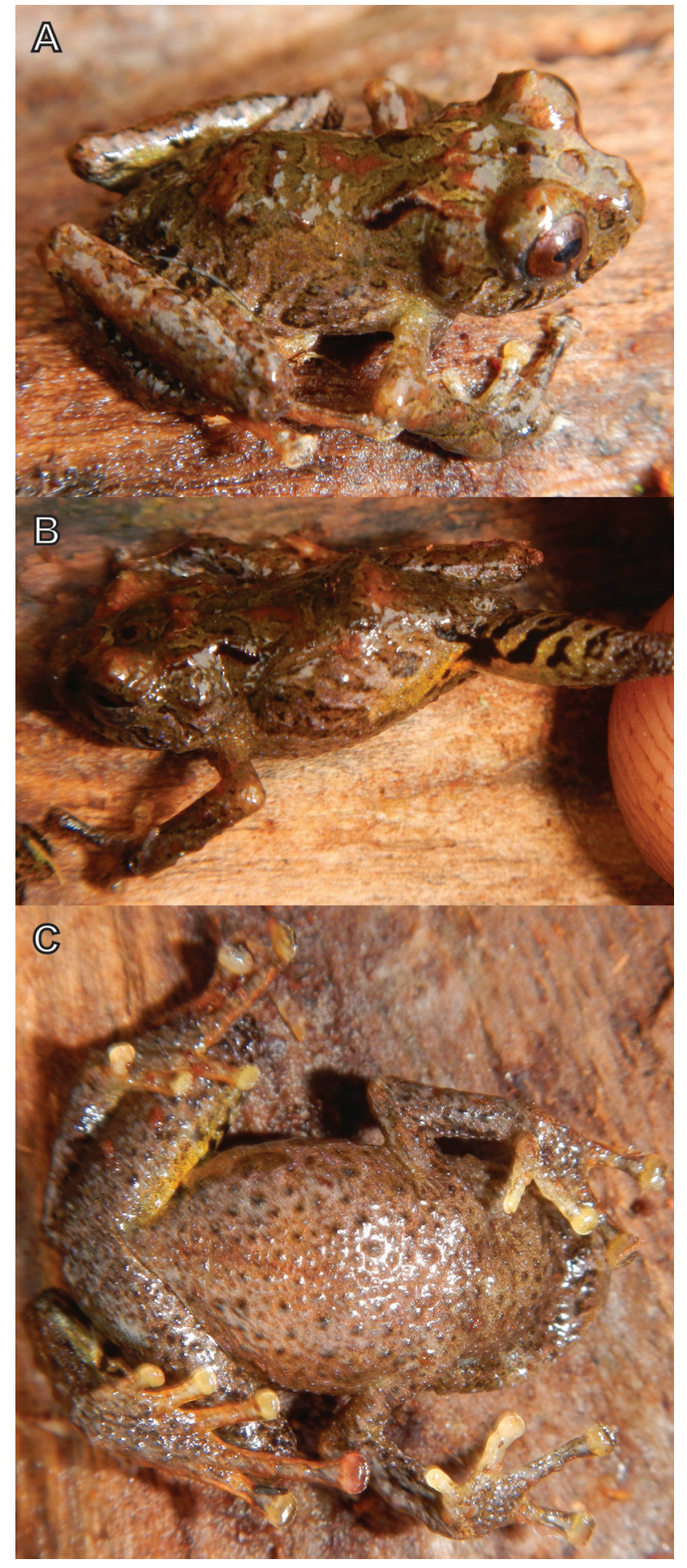

Fig. 3. Live holotype (MUSM 31102, SVL $14.1 \mathrm{~mm})$ of Pristimantis boucephalus sp. nov. A. Dorsal view. B. Dorsolateral view. C. Ventral view. Photos by E. Lehr. 
Table 2. Comparisons of $P$. boucephalus sp. nov. with other small and minute species of Pristimantis from Ecuador and Peru. Characters were taken from original species descriptions and the examined material. Presence of a character is indicated by ' + ', its absence by '-'.

\begin{tabular}{|c|c|c|c|c|c|c|}
\hline Character & $\begin{array}{l}\text { boucephalus } \\
\text { sp. nov. }\end{array}$ & andinognomus & caeruleonotus & minimus & minutulus & trachyblepharis \\
\hline Reference & this paper & $\begin{array}{l}\text { Lehr \& Coloma } \\
\quad(2008)\end{array}$ & $\begin{array}{l}\text { Lehr et al. } \\
\text { (2007) }\end{array}$ & $\begin{array}{l}\text { Terán-Valdez \& } \\
\text { Guayasamin } \\
(2010)\end{array}$ & $\begin{array}{c}\text { Duellman \& } \\
\text { Hedges (2007) }\end{array}$ & $\begin{array}{c}\text { Lynch \& } \\
\text { Duellman } \\
(1980)\end{array}$ \\
\hline $\begin{array}{l}\text { Male SVL } \\
(\mathrm{mm})\end{array}$ & $\begin{array}{c}13.4-14.5 \\
(\mathrm{n}=3)\end{array}$ & $\begin{array}{c}10.0-14.5 \\
(\mathrm{n}=21)\end{array}$ & $\begin{array}{c}11.6-14.6 \\
(\mathrm{n}=4)\end{array}$ & $\begin{array}{l}9.5-13.7 \\
(\mathrm{n}=46)\end{array}$ & $\begin{array}{c}13.1-17.6 \\
(\mathrm{n}=7)\end{array}$ & $\begin{array}{c}12.1-15.8 \\
(\mathrm{n}=20)\end{array}$ \\
\hline $\begin{array}{l}\text { Female SVL } \\
(\mathrm{mm})\end{array}$ & $\begin{array}{c}12.5 \\
(\mathrm{n}=1)\end{array}$ & $\begin{array}{c}12.6-17.9 \\
(\mathrm{n}=19)\end{array}$ & $\begin{array}{c}20.5-22.6 \\
(\mathrm{n}=4)\end{array}$ & $\begin{array}{c}15.3-18.9 \\
(\mathrm{n}=25)\end{array}$ & $\begin{array}{c}17.0-20.1 \\
(\mathrm{n}=3)\end{array}$ & $\begin{array}{c}15.8-19.2 \\
(\mathrm{n}=19)\end{array}$ \\
\hline Dorsolateral folds & - & + & + & - & - & - \\
\hline $\begin{array}{l}\text { Tympanic } \\
\text { membrane and } \\
\text { annulus }\end{array}$ & - & + & + & + & - & + \\
\hline Vocal slits & + & + & + & + & - & - \\
\hline Nuptial pads & - & - & - & - & - & - \\
\hline Lateral fringes & + & + & + & - & - or + & - \\
\hline $\begin{array}{l}\text { Elevational range } \\
\text { (m) }\end{array}$ & 2950 & $2450-2800$ & $2500-2900$ & $1250-1685$ & $250-1200$ & $100-1250$ \\
\hline
\end{tabular}

and areolate venter, but $P$. minutulus has the snout moderately long (short), males without vocal slits (present), groin with large yellow spot (greenish yellow with black blotches), and iris reddish gray (reddish copper with fine black vermiculation). Pristimantis caeruleonotus Lehr, Aguilar, Siu-Ting \& Jordán, 2007 from elevations of 2500-2900 m a.s.1. of humid montane forests in northern Peru has males of similar size (SVL 11.6-14.6 mm [n=4] vs 13.4-14.5 mm [n=3] in P. boucephalus sp. nov.; Lehr et al. 2007). Both P. caeruleonotus and P. boucephalus sp. nov. have fingers and toes with lateral fringes, heel with conical tubercle, and males that have vocal slits, but lack nuptial pads. However, P. caeruleonotus has a distinct tympanum (absent), dorsolateral folds (absent), small dentigerous processes of vomers (absent), a discoidal fold (absent), prominent dorsolateral folds ending in a sacral tubercle (absent), and a long snout with terminal papillae (short snout without papillae). Furthermore, P. caeruleonotus has the groin blackish brown with yellow and pale blue blotches (greenish yellow with black blotches). Pristimantis coronatus Lehr \& Duellman, 2007 is known from a single female specimen of $15.3 \mathrm{~mm}$ SVL from $2850 \mathrm{~m}$ a.s.l. in northern Peru (Lehr \& Duellman 2007). It shares with P. boucephalus sp. nov. the absence of dorsolateral folds and a tympanum, and the presence of conical tubercles on the upper eyelid and fingers and toes with lateral fringes. However, P. coronatus has dentigerous processes of vomers (absent), groin red and black (greenish yellow with black blotches), and the iris dark brown (reddish copper). Pristimantis trachyblepharis (Boulenger, 1918) from elevations of 100-1250 m a.s.l. in southern Ecuador and northern Peru and P. boucephalus sp. nov. have smooth dorsum, areolate venter, dorsolateral folds absent, and males that lack nuptial pads. However, P. trachyblepharis tends to have larger males (SVL 12.1-15.8 $\mathrm{mm}[\mathrm{n}=20]$ vs 13.4-14.5 $\mathrm{mm}[\mathrm{n}=3]$ in P. boucephalus sp. nov.), tympanum present (absent), males without vocal slits (present), dentigerous processes of vomers 

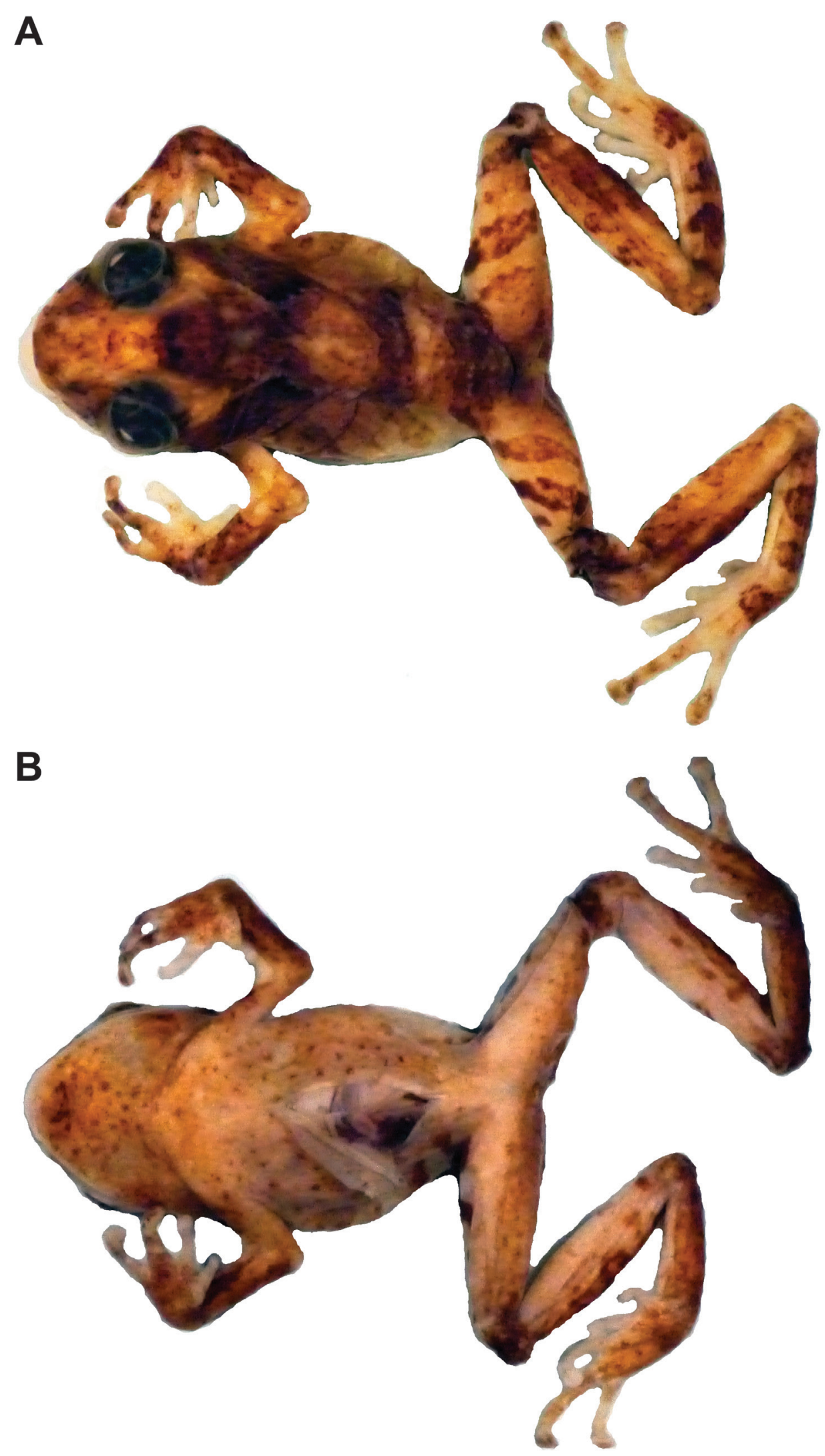

Fig. 4. Preserved holotype (MUSM 31102, SVL $14.1 \mathrm{~mm}$ ) of Pristimantis boucephalus sp. nov. A. Dorsal view. B. Ventral view. Photos by E. Lehr. 
(absent), and fingers and toes without lateral fringes (present) (Lynch \& Duellman 1980). Pristimantis andinognomus Lehr \& Coloma, 2008 from 2450-2800 m a.s.l. in the Cordillera Oriental in southern Ecuador (Zamora Chinchipe) has males of similar size (SVL 10.0-14.5 mm [n $=20]$ vs $13.4-14.5 \mathrm{~mm}$ $[\mathrm{n}=3]$ in P. boucephalus sp. nov.), males that have vocal slits but lack nuptial pads, fingers and toes with lateral fringes, and supernumerary plantar tubercles (Lehr \& Coloma 2008). However, Pristimantis andinognomus has short dorsolateral folds that end in a conical sacral tubercle (absent), tympanic membrane and tympanic annulus present (absent), a short snout with terminal tubercle (terminal tubercle absent), minute dentigerous processes of vomers (absent), flanks with tubercles coalescing into short ridges (ridges absent), heel with two enlarged tubercles (one heel tubercle), and inner tarsal fold present (absent). Pristimantis minimus Terán-Valdez \& Guayasamin, 2010 from the Cordillera del Condor in Ecuador at elevations between 1250 and $1685 \mathrm{~m}$ a.s.l. has smaller males on average (SVL 9.5-13.7 mm [n= 46] vs 13.4-14.5 mm [n=3] in P. boucephalus sp. nov.; Terán-Valdez \& Guayasamin 2010). Pristimantis minimus and P. boucephalus sp. nov. lack dorsolateral, discoidal and thoracic folds, have a short snout, and males have vocal slits present and nuptial pads absent. However, P. minimus has dentigerous processes of vomers (absent), fingers and toes without lateral fringes (present), heel without tubercles (heel with a conical tubercle), upper eyelid without enlarged tubercles (enlarged upper eyelid tubercles present), and has red iris with black reticulations (iris reddish copper with fine black vermiculation and narrow black vertical streak from pupil across lower half of iris).

Pristimantis boucephalus sp. nov. can be distinguished from other species of Pristimantis from Ecuador and Peru that are on average larger but have males of similar size as follows:

Pristimantis carvalhoi (Lutz, 1952) from the Amazonian lowlands and P. boucephalus sp. nov. both have males of similar size (SVL 13.4-14.8 mm vs 13.4-14.5 mm [n = 3] in P. boucephalus sp. nov.; Lynch 1980), no dorsolateral folds, and a groin with yellow coloration. However, P. carvalhoi has a long snout (short), tympanic annulus present (absent), prominent dentigerous processes of vomers (absent), vocal slits absent (present), and fingers and toes without lateral fringes (present). Pristimantis imitatrix (Duellman, 1978) from the Amazonian lowlands has slightly smaller males (SVL 13.0-14.0 mm [n = 9] vs 13.4-14.5 mm [n=3] in P. boucephalus sp. nov.; Duellman 2005) and shares with P. boucephalus sp. nov. the absence of a tympanum, dorsolateral folds, dentigerous processes of vomers, and nuptial pads, and both species have fingers and toes with lateral fringes. However, P. imitatrix lacks vocal slits (present), has the groin mottled black and white (greenish yellow with black blotches) and the iris is bronze (reddish copper). Pristimantis lirellus (Dwyer, 1995) from elevations of 470-1200 m a.s.l. in northern Peru and $P$. boucephalus sp. nov. both have males with vocal slits, and fingers and toes with lateral fringes, and both species lack a tympanum, dorsolateral folds, and nuptial pads, but $P$. lirellus has low longitudinal dermal ridges (absent), prominent dentigerous processes of vomers (absent), groin with single pale yellow to orange-yellow spot (greenish yellow with black blotches), and iris bronze to reddish brown (reddish copper). Pristimantis martiae (Lynch, 1974) from the Amazonian lowlands up to $1330 \mathrm{~m}$ a.s.l. and $P$. boucephalus sp. nov. lack dorsolateral folds, a tympanum, and nuptial pads, and both species have males with vocal slits, fingers and toes with lateral fringes. However, P. martiae has larger males (SVL 11.8-16.8 mm vs 13.4-14.5 mm [n = 3], Lynch 1980), small dentigerous processes of vomers (absent), a groin that is dull cream, pale orange or tan with brown to black bars or mottling (greenish yellow with black blotches), and bronze iris (reddish copper). Pristimantis croceoinguinis (Lynch, 1968) from the Amazonian lowland forests in Ecuador and Peru has larger males (13.9-18.2 mm vs 13.4-14.5 mm [ $\mathrm{n}=3$ ], Lynch 1968) which lack vocal slits (present). Pristimantis llosintuta (Köhler \& Lötters, 1999) from 2000-2200 m a.s.l. in Bolivia has a tympanum (absent) and much larger males (SVL 20.3-21.2 mm [n = 7] vs 13.4-14.5 mm [n = 3], Köhler \& Lötters 1999). Pristimantis cruciocularis (Lehr, Lundberg, Aguilar \& von May, 2006) from the YCNP and its surroundings and P. boucephalus sp. nov. are of similar size (SVL 11.4-15.4 [n=7] vs 13.4-14.5 mm [n=3]; Lehr et al. 2006) and share the absence of a tympanic annulus and membrane, but male $P$. cruciocularis lack vocal slits (present). 
Furthermore, $P$. cruciocularis has the iris with a cruciform mark (absent) and a groin that is orange-red (greenish yellow with black blotches). Pristimantis sp. Pui Pui and P. boucephalus sp. nov. share the absence of a tympanic annulus and membrane, but $P$. sp. Pui Pui is much larger (SVL up to $31.3 \mathrm{~mm}$ vs 13.4-14.5 mm [n $=3]$ ), and has a gray groin (greenish yellow with black blotches).

\section{Description of the holotype}

Head broader than body, as long as wide; head length $41.1 \%$ of SVL; head width $41.1 \%$ of SVL; cranial crests absent; snout short, rounded in dorsal view, rounded in lateral view (Figs 3, 5A-B); eye-nostril distance $50 \%$ of eye diameter; nostrils slightly protuberant, directed dorsolaterally; canthus rostralis short, broadly rounded in lateral view, weakly concave in dorsal view; loreal region slightly concave; lips rounded; upper eyelid each with an enlarged conical tubercle at its center and one enlarged conical tubercle at its posterior end; upper eyelid width $57.1 \%$ of IOD; few small tubercles on scapular region (see photos in life Fig. 3A-B); supratympanic fold short and broad, extending from posterior margin of upper eyelid slightly curved to insertion of arm; tympanic membrane and annulus absent; small low
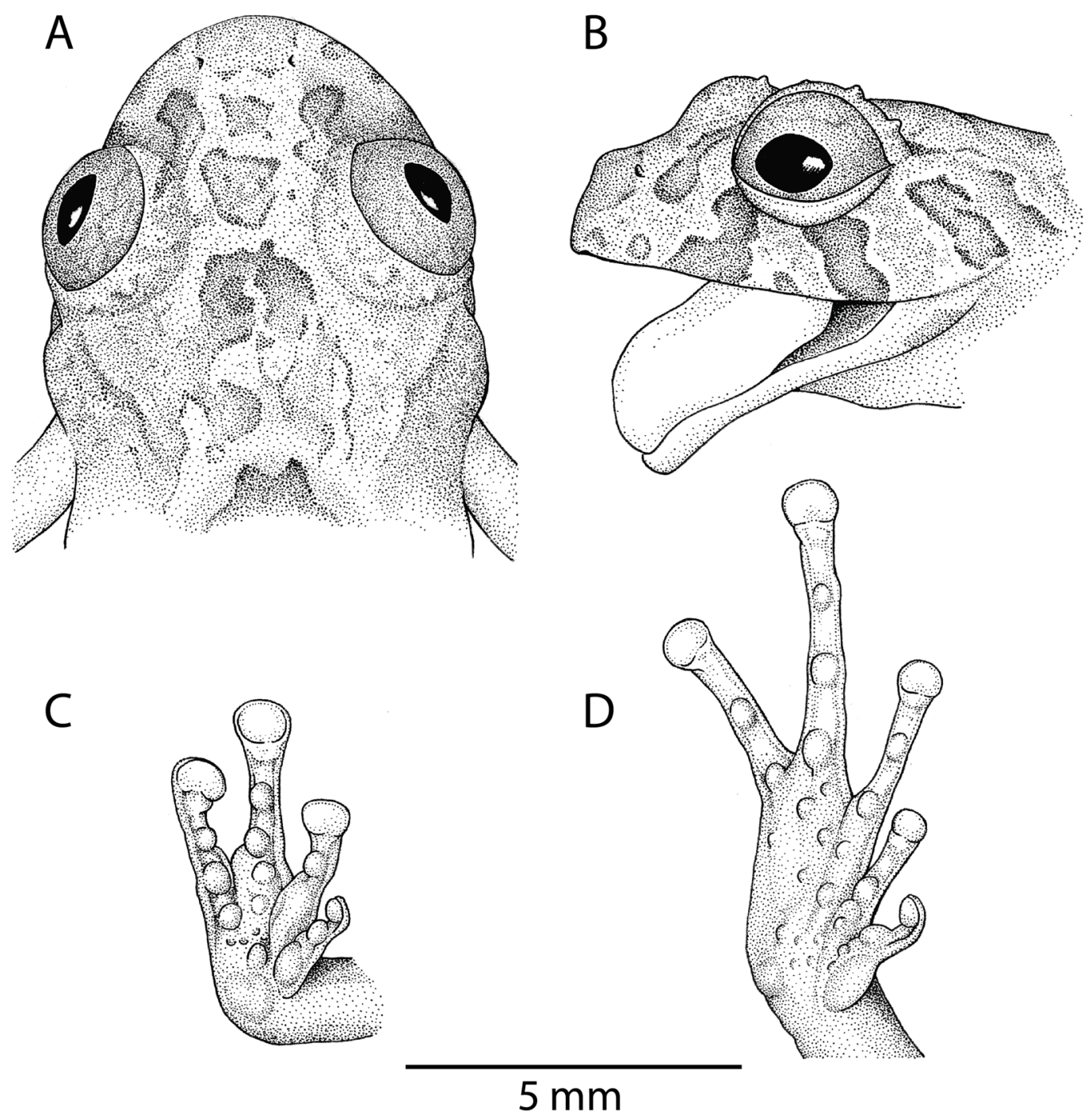

Fig. 5. Pristimantis boucephalus sp. nov., holotype (MUSM 31102). A. Dorsal view of head. B. Lateral view of head. C. Ventral view of hand. D. Ventral view of foot. Drawings by J. Moravec. 
postrictal tubercles present bilaterally. Choanae small, ovoid, not concealed by palatal shelf of maxilla; dentigerous processes of vomers absent; tongue oval, tongue width is about three-fourths of the tongue length, posterior half free.

Skin on dorsum and flanks smooth, with low scattered tubercles (denser on flanks than on dorsum), dorsolateral folds absent; occipital and scapular region with sinusoidal ridge; skin on throat, chest, and belly areolate, with scattered low tubercles; discoidal and thoracic folds absent; cloacal sheath short.

Outer ulnar surface with minute low tubercles; palmar tubercle partially divided distally; thenar tubercle ovoid; subarticular tubercles well defined, most prominent on base of fingers, round in ventral view, subconical in lateral view; supernumerary tubercles distinct, ovoid, approximately half the size of subarticular tubercles; fingers with lateral fringes; Finger I shorter than Finger II; discs on digits of fingers expanded, round (Fig. 5C).

Hind limbs moderately long, slender, tibia length $54.6 \%$ of SVL; foot length $48.9 \%$ of SVL; upper surfaces of hind limbs smooth, with low scattered tubercles; inner surface of thighs smooth, posterior and



Fig. 6. Paratypes of Pristimantis boucephalus sp. nov. in dorsal (upper row) and ventral (lower row) views. From left to right: $q$ (MUSM 24479), $\widehat{\partial}$ (MUSM 24477), $\widehat{\partial}$ (MUSM 24478), juvenile (MUSM 24474). Photos by E. Lehr. 
ventral surfaces of thighs weakly areolate; heels each with a prominent conical tubercle; outer surface of tarsus with scattered minute low tubercles; inner tarsal fold absent; inner metatarsal tubercle ovoid, two and a half times the size of round outer metatarsal tubercle; subarticular tubercles well defined, round in ventral view, subconical in lateral view; plantar supernumerary tubercles distinct, about half the size of subarticular tubercles; toes with lateral fringes; basal webbing present; discs expanded, round, less expanded than those on fingers; relative length of toes: $1<2<3<5<4$; disc on Toe III not reaching distal subarticular tubercle on Toe IV, disc on Toe V reaching distal subarticular tubercle on Toe IV; Fig. 5D.

\section{Measurements (in $\mathbf{m m}$ ) of the holotype}

SVL 14.1; HL 5.8; HW 5.8; ED 2.4; IOD 2.1; EW 1.2; IND 1.4; E-N 1.2; TL 7.7; FL 6.9.

\section{Coloration of the holotype in life (Fig. 3)}

The dorsal ground coloration is greenish gray with reddish-brown and scattered brown flecks surrounded by black; a reddish-brown blotch mid-dorsally behind the eyes; sinusoidal ridge on occipital and scapular region dark brown; upper lip with two irregularly shaped grayish-brown bars bordered by black on each side of head below eye, bars separated by an irregular pale tan blotch; narrow brown bar laterally in area of canthus rostralis, but not forming a canthal stripe, supratympanic stripe grayish brown, bordered by black; flanks pale greenish and pale reddish brown with scattered dark brown flecks; groin and anterior surfaces of thighs greenish yellow with black blotches and black stripes that extend dorsally to posterior surfaces of thighs; throat, chest, belly and thighs gray with pale reddish and greenish brown mottling and scattered dark gray flecks; palmar and plantar surfaces gray, fingers I and II cream, fingers III and IV gray except for cream discs, toes I and II cream, toes III-V gray with reddish-brown lateral fringes; iris reddish copper with fine black vermiculation and narrow black vertical streak from pupil across lower half of iris.

\section{Coloration of the holotype in preservative (Fig. 4)}

Dorsal coloration grayish tan with scattered brown flecks; brown blotch middorsally behind eyes; sinusoidal ridge on occipital and scapular region dark brown; upper lip with two irregularly shaped grayish-brown bars on each side of head below eye, bars separated by an irregular pale gray blotch; narrow brown bar laterally in area of canthus rostralis, but not forming a canthal stripe, supratympanic stripe grayish brown; flanks tan with scattered brown flecks; groin and anterior surfaces of thighs tan with black blotches and black stripes that extend dorsally to posterior surfaces of thighs; throat, chest, belly and thighs grayish tan with dark gray flecks; palmar and plantar surfaces pale gray, fingers I and II tan, fingers III and IV gray except for tan discs, toes I and II tan, toes III-V gray; iris gray with fine black vermiculation and black narrow vertical streak from pupil across lower half of iris.

\section{Variation}

All paratypes are similar to the holotype regarding morphology (Tables 3-4) and coloration pattern (Fig. 6). They can easily be assigned to the species by having a small size with a disproportionally large head with short snout. The juvenile specimen (MUSM 24474) has two prominent tarsal and two prominent ulnar tubercles on each hind limb. One male specimen (MUSM 24477) has black bars dorsally, laterally and ventrally on the tibia and a brown blotch midventrally on the throat. One specimen (MUSM 24479) is considered a subadult female because of its small size, presence of ovaries, but absence of ovarian eggs.

\section{Distribution, natural history, and threat status}

Pristimantis boucephalus sp. nov. is currently only known from the YCNP. The type locality (Figs 1,7) is located on a mountain crest at $2950 \mathrm{~m}$ a.s.l. covered with primary cloud forest. The holotype was found at night, sitting on a leaf at $1 \mathrm{~m}$ above the ground. Syntopic anurans included Pristimantis cf. 
Table 3. Measurements (in $\mathrm{mm}$ ) of the type series of Pristimantis boucephalus sp. nov. Abbreviations: $\mathrm{M}=\hat{\mathrm{O}} ; \mathrm{SF}=$ subadult $q ; \mathrm{J}=$ juvenile. For other abbreviations see Material and methods.

\begin{tabular}{cccccc}
\hline Character & $\begin{array}{c}\text { MUSM } \\
\mathbf{3 1 1 0 2}\end{array}$ & $\begin{array}{c}\text { MUSM } \\
\mathbf{2 4 4 7 8}\end{array}$ & $\begin{array}{c}\text { MUSM } \\
\mathbf{2 4 4 7 7}\end{array}$ & $\begin{array}{c}\text { MUSM } \\
\mathbf{2 4 4 7 9}\end{array}$ & $\begin{array}{c}\text { MUSM } \\
\mathbf{2 4 4 7 4}\end{array}$ \\
\hline Sex & M & M & M & SF & J \\
SVL & 14.1 & 13.4 & 14.5 & 12.5 & 10.0 \\
TL & 7.7 & 7.9 & 8.2 & 7.4 & 5.5 \\
FL & 6.9 & 7.6 & 7.4 & 6.3 & 5.4 \\
HL & 5.8 & 5.2 & 5.61 & 5.1 & 4.5 \\
HW & 5.8 & 5.5 & 5.8 & 5.2 & 4.5 \\
ED & 2.4 & 2.0 & 2.4 & 1.9 & 1.8 \\
IOD & 2.1 & 2.1 & 2.0 & 1.9 & 1.6 \\
EW & 1.2 & 1.8 & 1.6 & 1.5 & 1.5 \\
IND & 1.4 & 1.4 & 1.6 & 1.3 & 1.3 \\
N-E & 1.2 & 1.3 & 1.6 & 1.4 & 1.2 \\
\hline
\end{tabular}

aniptopalmatus (MUSM 31103-05), P. cf. mendax (MUSM 31101, 31107), and Phrynopus curator (MUSM 31106). We classify Pristimantis boucephalus sp. nov. as "Data Deficient" according to the IUCN red list criteria and categories (IUCN Standards and Petitions Subcommittee 2016) based on the limited information on its geographic range. Given that Pristimantis boucephalus sp. nov. occurs inside the YCNP, a long-term protection of this species should be granted.

\section{Discussion}

The molecular phylogeny (Fig. 2) shows that the new species, Pristimantis boucephalus sp. nov., belongs to a well-supported speciose clade, which comprises mainly montane but also some Amazonian lowland taxa from northern South America. The clade contains species from the Andes in the west and the Guiana Shield in the east, and corresponds well to a clade uncovered in other studies (Hedges et al. 2008; Pyron \& Wiens 2011; Padial et al. 2014). In addition, our results point out a surprisingly high phylogenetic diversity of Pristimantis associated with the relatively small area $\left(1220 \mathrm{~km}^{2}\right.$ between 460 and 3643 m elevation, Yallico \& Rose 1998) of the Cordillera Yanachaga. The six divergent lineages of Pristimantis that we identified in this study correspond with lineages detected in previous phylogenetic reconstructions of the genus (Hedges et al. 2008; Pyron \& Wiens 2011). Three lineages were assigned to species groups (Fig. 2), whereas the three other lineages remain unassigned to species groups (Padial et al. 2014). The high phylogenetic diversity indicates that members of Pristimantis probably colonized this region of the central Peruvian Andes through several independent events or underwent unusually high diversification in the region. Today, 18 species of Pristimantis (including three unnamed species) are known to occur in the cloud forests of the YCNP and its buffer zone (see Angulo et al. 2016).

In recent years, several new species of minute Pristimantis have been described from the Andes of Ecuador (Lehr \& Coloma 2008: P. andinognomus; Terán-Valdez \& Guayasamin 2010: P. minimus), and Peru (Duellman \& Hedges 2007: P. minutulus: Lehr et al. 2007: P. caeruleonotus; this paper), indicating that the diversity of small and minute species of this genus is highly underestimated due to difficulties in discovering them. With the description of P. boucephalus sp. nov., the number of Pristimantis known from Peru rises to 131 species (updated from AmphibiaWeb 2017).

Miniaturization of frogs has been documented in many species of different families (Wells 2007; Zimkus et al. 2012), and miniaturized frogs often have lost (e.g., digits) or reduced (e.g., phalanges) elements of 


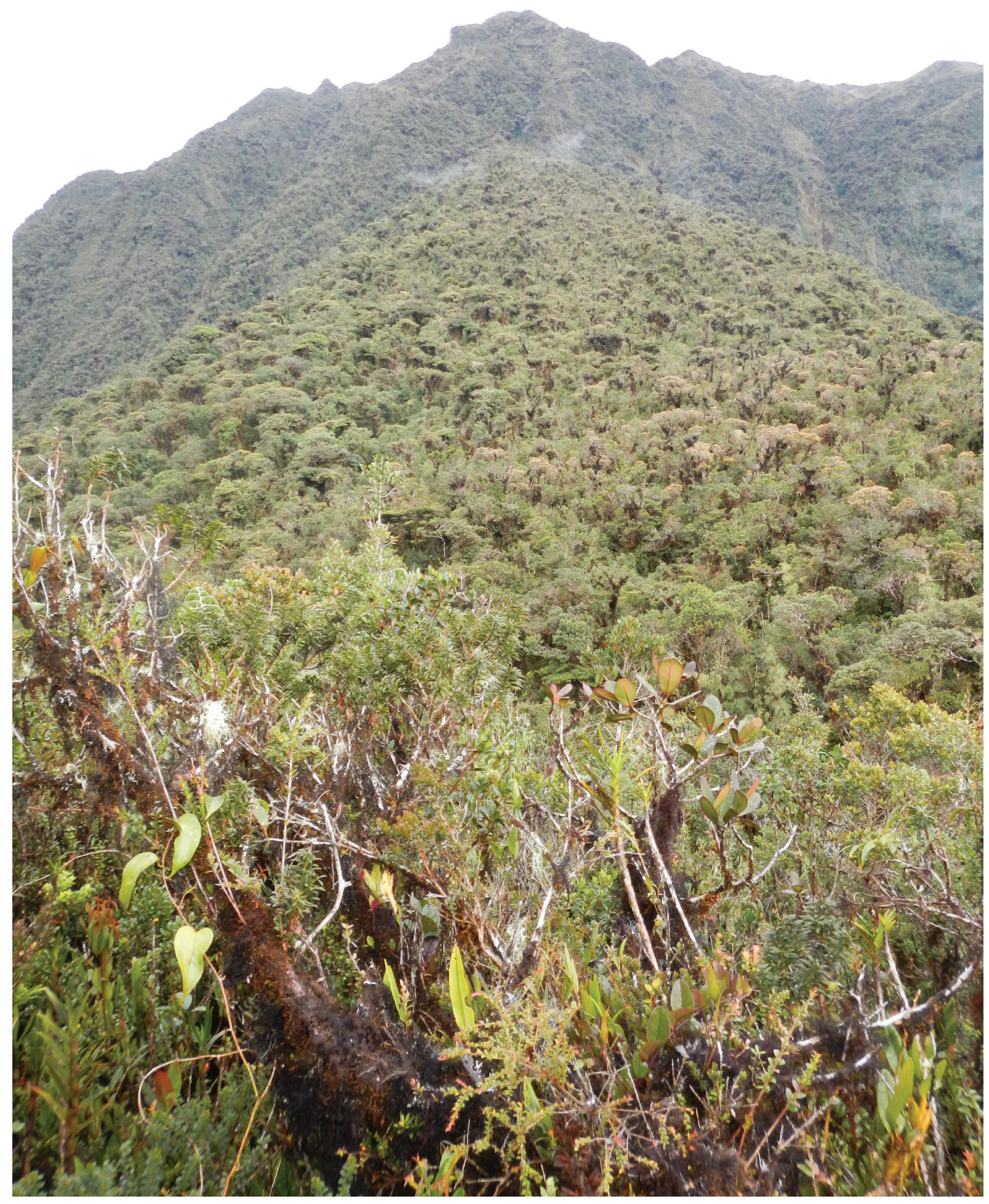

Fig. 7. Type locality of Pristimantis boucephalus sp. nov. in the Yanachaga-Chemillén National Park. Photo by E. Lehr. 
Table 4. Measurements (in $\mathrm{mm}$ ) and proportions of the male type series of Pristimantis boucephalus sp. nov.; ranges followed by means and one standard deviation in parentheses. For other abbreviations see Materials and methods.

\begin{tabular}{cc}
\hline Characters & Males $(\mathbf{n}=\mathbf{3})$ \\
\hline SVL & $13.4-14.5(14.0 \pm 0.5)$ \\
TL & $7.7-8.2(7.9 \pm 0.2)$ \\
FL & $6.9-7.6(7.3 \pm 0.3)$ \\
HL & $5.2-5.8(5.5 \pm 0.2)$ \\
HW & $5.5-5.8(5.7 \pm 0.1)$ \\
ED & $2.2-2.4(2.3 \pm 0.2)$ \\
IOD & $2.0-2.1(2.1 \pm 0.0)$ \\
EW & $1.2-1.8(1.5 \pm 0.2)$ \\
IND & $1.4-1.6(1.5 \pm 0.1)$ \\
E-N & $1.2-1.6(1.4 \pm 0.2)$ \\
TL/SVL & $0.55-0.59$ \\
FL/SVL & $0.49-0.57$ \\
HL/SVL & $0.39-0.41$ \\
HW/SVL & $0.40-0.41$ \\
HW/HL & $1.00-1.06$ \\
E-N/ED & $0.50-0.67$ \\
EW/IOD & $0.57-0.86$ \\
\hline
\end{tabular}

their skeleton, but rarely lose bones of the skull (Yeh 2002). Body proportions of P. boucephalus sp. nov. indicate that the process of miniaturization affected various body structures, leaving the size of the head less affected. However, whether the head of $P$. boucephalus sp. nov. experienced increased growth or the postcranial body experienced increased miniaturization cannot be determined at this moment.

\section{Acknowledgements}

We thank R. Brown (KU, Lawrence), B. Millán, J.H. Cordova (MUSM, Lima), K. de Queiroz (USNM, Washington DC), and A. Kupfer (SMNS, Stuttgart) for loan of material. The work by EL was funded by a Junior Faculty Leave provided by Illinois Wesleyan University and a Northern European Explorers Grant (GEFNE13-11) funded by National Geographic Society Science and Exploration Europe. The work of JM and VG was financially supported by the Ministry of Culture of the Czech Republic (DKRVO 2013/14, 2014/14, 2015/15, 2016/15, and 2017/15, National Museum Prague, 00023272), and V.G. also by the IVB institutional support (RVO: 68081766). Collecting ( $\mathrm{N}^{\circ}$ 008-2011-SERNANP-DGANP-JEF) and export permits ( $\mathrm{N}^{\circ}$ 007695-AG-DGFFS) were issued by the Ministerio del Ambiente, Lima, Peru. We are grateful for the helpful comments provided by two anonymous reviewers and thank L. Cozy for revising the English.

\section{References}

Altschul S.F., Gish W., Miller W., Myers E.W. \& Lipman D.J. 1990. Basic local alignment search tool. Journal of Molecular Biology 215: 403-410. https://doi.org/10.1016/S0022-2836(05)80360-2

AmphibiaWeb: Information on amphibian biology and conservation. [web application]. 2017. Berkeley, California: AmphibiaWeb. Available from http://amphibiaweb.org/ [accessed 13 May 2017]. 
Angulo A., von May R., Icochea J., Chaparro J.C., Hedges B., Lehr E., López D.G., Lundberg M. \& Moravec J. 2016. Parque Nacional Yanachaga-Chemillén, Pasco, Perú. Anfibios del bosque de nubes y su zona de amortiguamiento. Field Guides 738: 1-6.

Boulenger G.A. 1918. Descriptions of new South-American batrachians. Annals and Magazines of Natural History, Series 9 2: 427-433. https://doi.org/10.1080/00222931808673782

Castresana J. 2000. Selection of conserved blocks from multiple alignments for their use in phylogenetic analysis. Molecular Biology and Evolution 17: 540-552. https://doi.org/10.1093/oxfordjournals.molbev. $\underline{\mathrm{a} 026334}$

Clarke B.T. 1996. Small size in amphibians: its ecological and evolutionary implications. Symposia of the Zoological Society of London 69: 201-224.

Darriba D., Taboada G.L., Doallo R. \& Posada D. 2012. jModelTest 2: more models, new heuristics and parallel computing. Nature Methods 9: 772. https://doi.org/10.1038/nmeth.2109

Duellman W.E. 1978. Three new species of Eleutherodactylus from Amazonian Perú (Amphibia: Anura: Leptodactylidae). Herpetologica 34: 264-270.

Duellman W.E. 2005. Cuzco Amazonico: the Lives of Amphibians and Reptiles in an Amazonian Rainforest. Cornell University Press, Ithaca, New York.

Duellman W.E. \& Hedges S.B. 2005. Eleutherodactyline frogs (Anura: Leptodactylidae) from the Cordillera Yanachaga in Central Peru. Copeia 2005: 526-538. https://doi.org/10.1643/CH-05-019R

Duellman W.E. \& Hedges S.B. 2007. Three new species of Pristimantis (Lissamphibia, Anura) from montane forests of the Cordillera Yanachaga in Central Peru. Phyllomedusa 6: 119-135. https://doi. org/10.11606/issn.2316-9079.v6i2p119-135

Duellman W.E. \& Lehr E. 2009. Terrestrial-breeding Frogs (Strabomantidae) in Peru. Natur und TierVerlag, Münster.

Guindon S. \& Gascuel O. 2003. A simple, fast and accurate algorithm to estimate large phylogenies by maximum-likelihood. Systematic Biology 52: 696-704. https://doi.org/10.1080/10635150390235520

Hedges S.B., Duellman W.E. \& Heinicke H. 2008. New world direct-developing frogs (Anura: Terrarana): molecular phylogeny, classification, biogeography, and conservation. Zootaxa 1737: 1-182.

Heinicke M.P., Duellman W.E., Trueb L., Means D.B., MacCulloch R.D. \& Hedges S.B. 2009. A new frog family (Anura: Terrarana) from South America and an expanded direct-developing clade revealed by molecular phylogeny. Zootaxa 2211: 1-35.

Huelsenbeck J.P. \& Rannala B. 2004. Frequentist properties of Bayesian posterior probabilities of phylogenetic trees under simple and complex substitution models. Systematic Biology 53: 904-913. https://doi.org/10.1080/10635150490522629

IUCN Standards and Petitions Subcommittee. 2016. Guidelines for using the IUCN Red List categories and criteria. Version 12. Prepared by the Standards and Petitions Subcommittee. Available from http:// www.iucnredlist.org/documents/RedListGuidelines.pdf [accessed 27 Apr. 2017].

Katoh K. \& Standley D.M. 2013. MAFFT multiple sequence alignment software version 7: improvements in performance and usability. Molecular Biology and Evolution 30: 772-780. https://doi.org/10.1093/ $\underline{\text { molbev/mst010 }}$

Köhler J. \& Lötters S. 1999. New species of the Eleutherodactylus unistrigatus group (Amphibia: Anura: Leptodactylidae) from montane rain forest of Bolivia. Copeia 1999: 422-427. https://doi. org/10.2307/1447487 
Lehr E. \& Coloma L.A. 2008. A minute new Ecuadorian Andean frog (Anura: Strabomantidae, Pristimantis). Herpetologica 64: 354-367. https://doi.org/10.1655/07-089.1

Lehr E. \& Duellman W.E. 2007. A diminutive new species of Pristimantis (Amphibia: Anura: Leptodactylidae) from northern Peru. Salamandra 43: 165-171.

Lehr E., Lundberg M., Aguilar C. \& von May R. 2006. New species of Eleutherodactylus (Anura: Leptodactylidae) from the eastern Andes of central Peru with comments on central Peruvian Eleutherodactylus. Herpetological Monographs 20:105-128.

Lehr E., Aguilar C., Siu-Ting K. \& Jordán J.C. 2007. Three new species of Pristimantis (Anura: Leptodactylidae) from the Cordillera de Huancabamba in northern Peru. Herpetologica 63: 519-536. https://doi.org/10.1655/0018-0831(2007)63\%5B519:TNSOPA\%5D2.0.CO;2

Lynch J.D. 1968. Two new frogs of the genus Eleutherodactylus from eastern Ecuador (Amphibia: Leptodactylidae). Journal of Herpetology 2: 129-135. https://doi.org/10.2307/1563112

Lynch J.D. 1980. A taxonomic and distributional synopsis of the Amazonian frogs of the genus Eleutherodactylus. American Museum Novitates 2696: 1-24.

Lynch J.D. \& Duellman W.E. 1980. The Eleutherodactylus of the Amazonian slopes of the Ecuadorian Andes (Anura: Leptodactylidae). Miscellaneous Publication of the Museum of Natural History, University of Kansas 69: 1-86.

Lynch J.D. \& Duellman W.E. 1997. Frogs of the genus Eleutherodactylus in western Ecuador: systematics, ecology, and biogeography. Special Publication of the Natural History Museum, University of Kansas 23: 1-236.

Moravec J., Aparicio J., Guerrero-Reinhard M., Calderón G., Jungfer K.-H. \& Gvoždík V. 2009. A new species of Osteocephalus (Anura: Hylidae) from Amazonian Bolivia: first evidence of tree frog breeding in fruit capsules of the Brazil nut tree. Zootaxa 2215: 37-54.

Morgulis A., Coulouris, G., Raytselis Y., Madden T.L., Agarwala R. \& Schäffer A.A. 2008. Database indexing for production MegaBLAST searches. Bioinformatics 24: 1757-1764. https://doi.org/10.1093/ bioinformatics/btn322

Padial J.M., Grant T. \& Frost D.R. 2014. Molecular systematics of terraranas (Anura: Brachycephaloidea) with an assessment of the effects of alignment and optimality criteria. Zootaxa 3825: 1-132. https://doi.org/10.11646/zootaxa.3825.1.1

Palumbi S., Martin A., Romano S., McMillan W.O., Stice L. \& Grabowski G. 1991. The Simple Fool's Guide to PCR. Version 2. University of Hawaii, Honolulu.

Pyron R.A. \& Wiens J.J. 2011. A large-scale phylogeny of Amphibia including over 2800 species, and a revised classification of extant frogs, salamanders, and caecilians. Molecular Phylogenetics and Evolution 61: 543-583. https://doi.org/10.1016/j.ympev.2011.06.012

Rambaut A., Suchard M.A., Xie W. \& Drummond A.J. 2013. Tracer. MCMC Trace Analysis Tool Version v1.6.0. Available from http://tree.bio.ed.ac.uk/software/tracer/ [accessed 27 Apr. 2017].

Ron S.R., Guayasamin J.M., Yanez-Muñoz M.H., Merino-Viteri A., Ortiz D.A. \& Nicolalde D.A. 2017. AmphibiaWebEcuador. Version 2017.0. Museo de Zoología, Pontificia Universidad Católica del Ecuador. Available from http://zoologia.puce.edu.ec/Vertebrados/anfibios [accessed 13 May 2017].

Ronquist F., Teslenko M., Van Der Mark P., Ayres D.L., Darling A., Höhna S., Larget B., Liu L., Suchard M.A. \& Huelsenbeck J.P. 2012. MrBayes 3.2: efficient Bayesian phylogenetic inference and model choice across a large model space. Systematic Biology 61: 539-542. https://doi.org/10.1093/ sysbio/sys029 
SERNANP. 2010. Guía Oficial De Áreas Naturales Protegidas Del Perú. Lima, Peru.

Swofford D.L. 2003. PAUP*. Phylogenetic Analysis Using Parsimony (* and other methods). Version 4. Sinauer Associates, Sunderland, Massachusetts.

Terán-Valdez A. \& Guayasamin J.M. 2010. The smallest terrestrial vertebrate of Ecuador: A new frog of the genus Pristimantis (Amphibia: Strabomantidae) from the Cordillera del Cóndor. Zootaxa 2447: $53-68$.

Vences M., Nagy Z.T., Sonet G. \& Verheyen E. 2012. DNA barcoding amphibians and reptiles. In: Kress W.J. \& Erickson D.L. (eds) DNA Barcodes: Methods and Protocols. Methods in Molecular Biology 858: 79-107. Humana Press, New York. https://doi.org/10.1007/978-1-61779-591-6 5

Wells K. 2007. The Ecology and Behaviour of Amphibians. The University of Chicago Press, Chicago, London.

Yallico L.A. \& Rose D.A. 1998. 12. Peru: Yanachaga-Chemillén National Park. In: Brandon, K., Redford K.H. \& Sanderson S.E. (eds) Parks in Peril. People, Politics, and Protected Areas. Island Press, The Nature Conservancy, Washington, DC: 353-371.

Yeh J. 2002. The effect of miniaturized body size on skeletal morphology of frogs. Evolution 56: 628641. https://doi.org/10.1111/j.0014-3820.2002.tb01372.x

Zhang Z., Schwartz S., Wagner L. \& Miller W. 2000. A greedy algorithm for aligning DNA sequences. Journal of Computational Biology 7: 203-214. https://doi.org/10.1089/10665270050081478

Zimkus B.M., Lawson L., Loader S.P. \& Hanken J. 2012. Terrestrialization, miniaturization and rates of diversification in African puddle frogs (Anura: Phrynobatrachidae). PLoS ONE 7(4): e35118: 1-11. https://doi.org/10.1371/journal.pone.0035118

Manuscript received: 14 May 2016

Manuscript accepted: 29 November 2016

Published on: 2 June 2017

Topic editor: Rudy Jocqué

Desk editor: Kristiaan Hoedemakers

Printed versions of all papers are also deposited in the libraries of the institutes that are members of the EJT consortium: Muséum national d'Histoire naturelle, Paris, France; Botanic Garden Meise, Belgium; Royal Museum for Central Africa, Tervuren, Belgium; Natural History Museum, London, United Kingdom; Royal Belgian Institute of Natural Sciences, Brussels, Belgium; Natural History Museum of Denmark, Copenhagen, Denmark; Naturalis Biodiversity Center, Leiden, the Netherlands; Museo Nacional de Ciencias Naturales-CSIC, Madrid, Spain; Real Jardín Botánico de Madrid CSIC, Spain. 


\section{Appendix}

Comparative specimens examined:

Phrynopus curator Lehr, Moravec \& Cusi, 2012 (1): Peru: Pasco, Yanachaga-Chemillén National Park (Sector San Daniel), Distrito de Huancabamba, Provincia de Oxapampa, 2950 m, MUSM 31106.

Pristimantis cf. aniptopalmatus (Duellman \& Hedges, 2005) (3): Peru: Pasco, Yanachaga-Chemillén National Park (Sector San Daniel), Distrito de Huancabamba, Provincia de Oxapampa, 2950 m, MUSM 31103-05.

Pristimantis cruciocularis (Lehr, Lundberg, Aguilar \& von May, 2006) (2): Peru: Pasco, YanachagaChemillén National Park (Sector San Daniel), Distrito de Huancabamba, Provincia de Oxapampa, ca 2900 m, MUSM 31140, MUSM 31146.

Pristimantis imitatrix (Duellman, 1978) (2): Peru: Madre de Dios, Cusco Amazónico, 15 km E of Puerto Maldonado, 200 m, MUSM 7348, MUSM 14605.

Pristimantis cf. mendax (Duellman, 1978) (2): Peru: Pasco, Yanachaga-Chemillén National Park (Sector San Daniel), Distrito de Huancabamba, Provincia de Oxapampa, 2950 m, MUSM 31101, MUSM 31107.

Pristimantis minutulus Duellman \& Hedges, 2007 (10): Peru: Huánuco, Panguana, SMNS 13017-22; Pasco: 0.0-1.5 km W of Cacazu, 900 m, KU 291677, KU 291679, KU 291680, KU 308608.

Pristimantis trachyblepharis (Boulenger, 1918) (7): Ecuador: Pastaza, Puyo, $5 \mathrm{~km}$ SSE of Hacienda Madrid, USNM 233386; Puyo, USNM 233388; Tungurahua, Río Negro, USNM 233391, USNM 233394, USNM 233397-99.

Pristimantis sp. Pui Pui (3): Peru: Junín, Pui Pui Protected Forest, 1700-1800 m, NMP6V 75063-65. 